\title{
触 New Disease Reports \\ First report of Wisteria vein mosaic virus on Wisteria sinensis in Iran
}

M. Al Jaberi, M. Zakiaghl and M. Mehrvar*

Plant Protection Department, School of Agriculture, Ferdowsi University of Mashhad, Azadi Square, Mashhad 9177948978, Iran

*E-mail: mehrvar@um.ac.ir

Received: 15 Oct 2018. Published:06 Nov 2018.

Wisteria vein mosaic virus (WVMV) is a member of the Potyvirus genus in the family Potyviridae (Bos, 1970). The virus has been reported in Wisteria spp. in Australasia, China, the United States, and a number of European countries (Clover et al., 2003, 2015; Liang et al., 2004). In August 2017, a plant of W. sinensis in the Pardis campus of the Ferdowsi University of Mashhad, in the northeast of Iran was observed to have mosaic and chlorotic mottling on leaves (Fig. 1) which resembled the symptoms caused by wisteria mosaic disease (Bos, 1970; Clover et al., 2003; Liang et al., 2004).

RNA was extracted from the symptomatic plant with an RNeasy Plant Mini Kit (Qiagen, Germany) and tested using generic potyvirus primers oligo1n/oligo2n (Marie-Jeanne et al., 2000), CIF/CIR (Ha et al., 2008) and WVMV-specific primers WVMVF1/WVMVR1 (Clover et al., 2003). Amplicons of the expected sizes, 327, 700 and 703 bp respectively, were obtained. The larger products were cloned and then bi-directionally sequenced (GenBank Accession no. MH800196). A BLAST search in GenBank showed $90 \%$ nucleotide sequence identity with WVMV from China (AY656816).

During 2017, 12 further samples were collected from symptomatic plants in the Pardis campus of Ferdowsi University of Mashhad (W. sinensis cv. Prolific). These samples all tested positive using the WVMVF1/WVMVR1 primers. To our knowledge this is the first report of WVMV infecting $W$. sinensis in Iran. Approximately $10 \%$ of the Wisteria plants in the Pardis campus of Ferdowsi University of Mashhad were infected with WVMV. Infected plants appeared to be randomly distributed and were of ten situated adjacent to healthy plants. It seems likely that the disease is spread primarily through vegetative propagation rather than by aphid or mechanical transmission. This disease reduces the quality and value of the ornamental plant by inducing chlorosis and mottling of the leaves.

\section{References}

Bos L, 1970. The identification of three new viruses isolated from Wisteria and Pisum in the Netherlands, and the problem of variation within the potato virus Y group. Netherlands Journal of Plant Pathology 76, 8-46. http://dx.doi.org/10.1007/BF01976763

Clover GRG, Tang Z, Smales TE, Pearson MN, 2003. Taxonomy of Wisteria vein mosaic virus and extensions to its host range and geographical distribution. Plant Pathology 52, 92-96.

http://dx.doi.org/10.1046/j.1365-3059.2003.00798.x

Clover GRG, Denton JO, Denton GJ, 2015. First report of Wisteria vein mosaic virus on Wisteria spp. in the United Kingdom. New Disease Reports 31, 1. http://dx.doi.org/10.5197/j.2044-0588.2015.031.001

Ha C, Coombs S, Revill PA, Harding RM, Vu M, Dale JL, 2008. Design and application of two novel degenerate primer pairs for the detection and complete genomic characterization of potyviruses. Archives of Virology 153, 25-36. http://dx.doi.org/10.1007/s00705-007-1053-7

Liang WX, Song LM, Li Y, Tian GZ, Li HF, Fan ZF 2004. First report of Wisteria vein mosaic virus in China. Plant Pathology 53, 516. http://dx.doi.org/10.1111/j.1365-3059.2004.01035.x

Marie-Jeanne V, Ioos R, Peyre J, Alliot B, Signoret P, 2000.

Differentiation of Poaceae potyviruses by reverse transcription-polymerase chain reaction and restriction analysis. Journal of Phytopathology 148, 141-151. http://dx.doi.org/10.1046/j.1439-0434.2000.00473.x

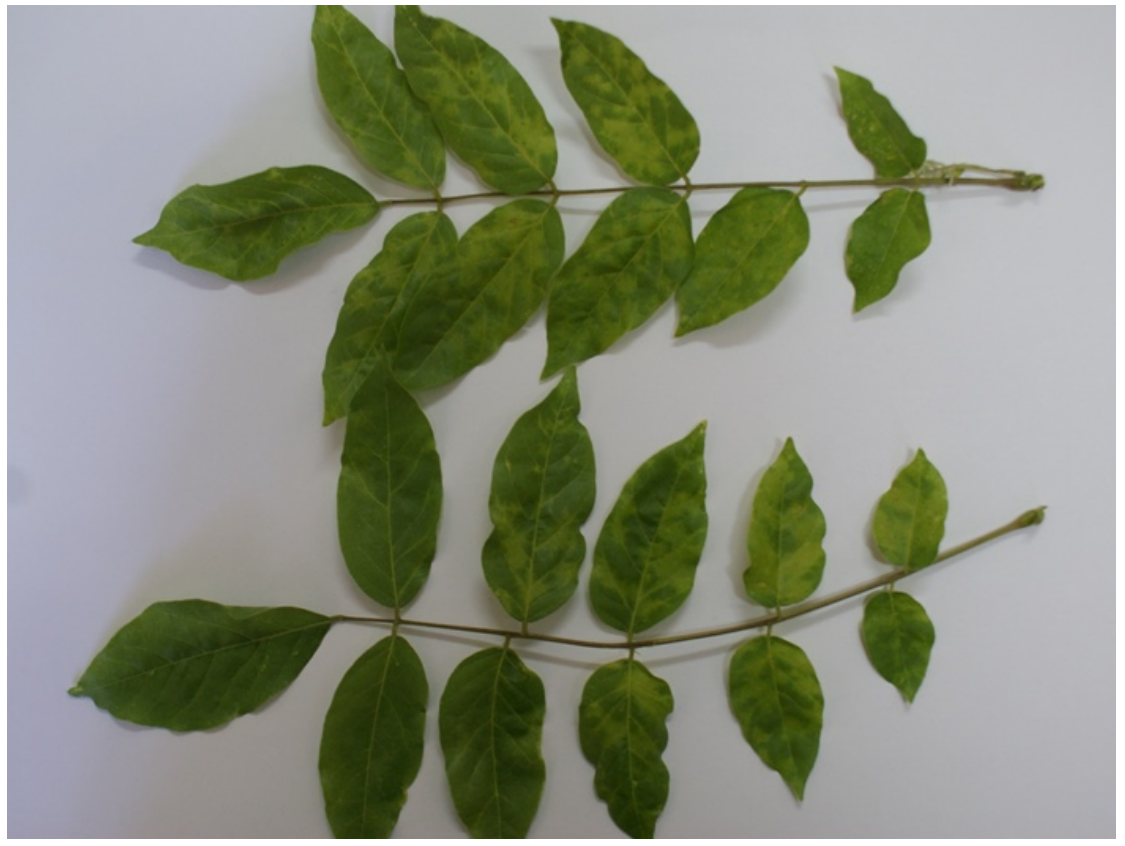

Figure 1

To cite this report: Al Jaberi M, Zakiaghl M, Mehrvar M, 2018. First report of Wisteria vein mosaic virus on Wisteria sinensis in Iran. New Disease Reports 38, 18. http://dx.doi.org/10.5197/j.2044-0588.2018.038.018

(c) 2018 The Authors

This report was published on-line at www.ndrs.org.uk where high quality versions of the figures can be found. 